FILIP WRÓBLEWSKI

Uniwersytet Jagielloński

\title{
O drodze do antropologii, badaniach terenowych i etyce z Aleksandrem Posern-Zielińskim rozmawia Filip Wróblewski ${ }^{1}$
}

Filip Wróblewski: Jak to się stało, że trafił Pan na antropologiczną drogę?

Aleksander Posern-Zieliński: Kiedy podejmowałem decyzję o wyborze kierunku studiów, moje zainteresowania ogniskowały się na pograniczu archeologii, historii kultury, dziejów religii i etnologii. W szkole średniej nie zdawałem sobie w pełni sprawy z tego, że takie dyscypliny istnieją; przede wszystkim interesowały mnie pierwociny wielkich cywilizacji. Szczególnie frapowała mnie mitologia, w tym także mitologia Słowian. Robiłem nawet, na swój prywatny użytek, słownik bóstw i demonów - do dziś zachowałem te zapiski. Czytałem wówczas słynną Stowiańszczyznę pierwotna (Labuda 1954). W związku z zainteresowaniem mitologią wahałem się, czy nie pójść na archeologię, bo zauważyłem, że starożytna Słowiańszczyzna $\mathrm{w}$ większym stopniu stanowi pole badawcze archeologii niż historii. Ta ostatnia mniej mnie interesowała, bo dominowała wówczas historia wydarzeniowa, wypełniona datami i faktami, które nic mi nie mówiły o procesach.

Interesujących mnie informacji było mało, a dostęp do nich był trudny. Wędrowałem zatem po antykwariatach i szperałem w rozmaitych książkach. I tak trafiłem do Muzeum Archeologicznego w Poznaniu. Do tamtejszej biblioteki poszedłem po jakąś książkę. Zbieg okoliczności sprawił, że zainteresował

1 Niniejszy materiał stanowi fragment rozmowy przeprowadzonej w ramach projektu badawczego „Etnografia jako doświadczenie osobiste. Generacyjne uwarunkowania przemian metodologii i praktyk badawczych" realizowanego w latach 2011-2013, finansowanego przez Narodowe Centrum Nauki (grant numer 2011/01/N/HS3/03273). Za pomoc w transkrypcji wywiadu dziękuję Karolinie Kolanowskiej. Redakcja rozmowy, bibliografia, przypisy dolne i śródtekstowe - Filip Wróblewski. Wywiad autoryzowano. 
się mną jeden z pracowników, który zapytał, dlaczego potrzebuję książek dotyczących tego typu tematyki. Wyjaśniłem mu moje zainteresowania, zostałem uważnie wysłuchany i w odpowiedzi usłyszałem: „Słuchaj młody człowieku, ciebie nie interesuje archeologia, musisz pójść na etnografię". Okazało, że był to Witold Armon (por. Armon 2007), jeden z uczniów słynnego profesora etnologii Eugeniusza Frankowskiego (por. Armon K., Armon W. 2007). Ta rozmowa była bardzo pomocna, ponieważ otrzymałem nie tylko dodatkowe wskazówki dotyczące poszukiwanej literatury, lecz także dowiedziałem się, gdzie jest na uniwersytecie poznańskim Katedra Etnografii. W ten sposób dotarłem wtedy do profesor Marii Frankowskiej (por. Paradowska 2002), która później została moją mistrzynią, i po tym spotkaniu zacząłem poważnie myśleć o etnografii jako kierunku moich studiów.

W tym wyborze utwierdziło mnie coś jeszcze. Mianowicie, w okresie przedmaturalnym, obok chęci poznania mitologii słowiańskiej - podobnie jak sporo młodych ludzi - zacząłem się interesować cywilizacjami prekolumbijskimi, oczywiście głównie Inkami. Ukazała się wówczas książka Rudolfa Noconia (1958) Dzieje, kultura i upadek Inków. Nabyłem ją, nie zważając na cenę, i z wielkim zainteresowaniem czytałem jej fragmenty, a potem chodziłem do Katedry Etnografii na dalsze konsultacje dotyczące literatury na ten temat. Nie pamiętam już, z kim się wówczas spotykałem, ale właśnie wtedy utwierdziłem się ostatecznie w przekonaniu, że muszę się zapisać na etnografię. Okazało się, że kierunek ten został utworzony, a w zasadzie reaktywowany, dwa lub trzy lata wcześniej ${ }^{2}$, zanim podjąłem te studia w $1960 \mathrm{r}$. Konsultacje, na które uczęszczałem jako licealista, dały mi przeświadczenie, że albo zajmę się problemami wierzeniowymi, albo badaniami latynoamerykanistycznymi.

Same studia były dla mnie ogromnym zaskoczeniem in plus, ponieważ nie wspominam mile szkoły średniej (jako instytucji), która ze względu na ówczesny program była dla mnie uciążliwa i nieatrakcyjna. Większość czasu spędzałem wówczas z kolegami poza szkołą albo w samotności oddawałem się lekturom książek z publicznej biblioteki, które natychmiast „pożerałem”. Zajmowałem się wtedy swoimi „etnograficznymi" pasjami, z którymi jednak nie zdradzałem się przed kolegami, aby nie wypaść na kogoś, kto ma "dziwne", nietypowe dla wieku zainteresowania.

\section{Gdy idzie o to, co „etnograficzne”, to czy bliższa jest Panu etnografia, etno- logia czy antropologia?}

\footnotetext{
${ }^{2}$ W ramach reformy studiów wyższych, przygotowywanej w latach 1948-1949, decydenci Ministerstwa Szkolnictwa Wyższego podjęli decyzję o likwidacji samodzielnych studiów etnologicznych, uznając je za wytwór nauki burżuazyjnej. Wzorem nauki radzieckiej połączono trzy dotąd odrębne kierunki - archeologię pradziejową (prehistorię), archeologię śródziemnomorską (klasyczną) oraz etnografię - tworząc w ich miejsce historię kultury materialnej. Kształcenie $z$ tego zakresu prowadziły tylko cztery uniwersytety: w Krakowie, Poznaniu, Warszawie i Wrocławiu. Jednocześnie uprawnień do kształcenia z etnografii nie otrzymały lub utraciły je ośrodki w Lublinie, Łodzi i Toruniu. Studia z historii kultury materialnej prowadzono w latach 1950-1956. O przywróceniu samodzielnych studiów etnograficznych w Poznaniu w 1957 r. wzmiankuje Jacek Bednarski (2011: 103).
} 
To dla mnie nie ma żadnego istotnego znaczenia. To tylko kwestia terminologii, a nie przedmiotu badań. Przykładowo, kiedy odwiedzam kraje Ameryki Łacińskiej, w których ekwiwalentem etnologii jest antropologia społeczna, to używam akceptowanego tam terminu, bo nie ma innej możliwości, by się adekwatnie i zrozumiale dla miejscowych przedstawiać. Jeśli natomiast pada pytanie: kim się czuję w kontekście tego, że mamy tu, w Poznaniu, na Uniwersytecie im. Adama Mickiewicza, Instytut Etnologii i Antropologii Kulturowej, to wówczas mam poważny dylemat. Zawsze byłem w kłopotliwym położeniu i trochę w opozycji do profesora Michała Buchowskiego, obecnego szefa tej placówki, którą kierowałem przez wiele lat. Stoi on bowiem na stanowisku - jeśli go dobrze rozumiem - przeciwstawiania antropologii społecznej, jako tej najważniejszej, antropologii kulturowej, lub w ogóle dezawuowania antropologii kulturowej. Osobiście, ze względu na uprawiane pola badawcze, uważam się za antropologa społecznego, ale antropologię społeczną lokuję na piętrze niższym aniżeli antropologię kulturową. Postrzegam ją zatem jako pewną subdyscyplinę antropologiczną, ponieważ bada ona przede wszystkim stosunki społeczne, takie jak choćby w moim przypadku - kwestie z zakresu postkolonialnych relacji władzy czy problemy samoorganizowania się ludności tubylczej, a są to zagadnienia, które klasycznie podpadają pod antropologię społeczną. Jeśli bym jednak badał a nie czynię tego - pola kognitywne, mity i mentalne struktury kształtujące tradycje indiańskie na Wyżu Andyjskim, to z pewnością nie byłbym antropologiem społecznym (w wąskim rozumieniu tego pojęcia). Dla mnie antropologia społeczna to dziedzina, która zajmuje się relacjami społecznymi, ale spogląda na nie przez pryzmat wzorców kulturowych; postępuję więc przeciwnie do socjologa, którego te aspekty mniej interesują. Tak więc jestem zarówno antropologiem kulturowym, jak i (na niższym piętrze) antropologiem społecznym. Na kolejnych etapach życia uprawiałem nieco odmienne specjalizacje (etnoreligioznawstwo, historię nauki, etnohistorię, badania polonijne), a obecnie lokuję się sam w obszarze antropologii polityki, ta zaś jest z pewnością częścią antropologii społecznej. Wszystko zależy od rozkładu akcentów. Biorąc za przykład krakowski ośrodek etnologiczny, w którym to antropologia społeczna prawie nie jest obecna, albo jest słabo reprezentowana, to można stwierdzić, że związane z tym środowiskiem osoby zajmują się w większym stopniu antropologią kulturową, podejmując się przykładowo - analiz literatury, mitów, idei, roli tradycji czy też znaczenia tak zwanych struktur długiego trwania, a więc zagadnień, których w Poznaniu nie badamy.

Wracając do moich osobistych inspiracji badawczych, to oczywiście, że przechodziłem przez wiele etapów autoidentyfikacji naukowej. Zawsze jednak zdawałem sobie sprawę z tego, że nazwa uprawianej dyscypliny ma drugorzędne znaczenie. To tylko nazwa, która jest pewnego rodzaju emblematem instytucjonalnym zmieniającym się tak jak samochody - czy podróżuję nowym „mercedesem", czy też jadę jakimś starym autem, jest ważne, aby w miarę sprawnie dojechać do wyznaczonego punktu. Stąd można wyprowadzić wniosek, że jest istotne, abyśmy stale walczyli o zachowanie naszej naukowej tożsamości jako 
antropologowie, bo nazwa ta, niezależnie od wewnętrznych sporów, ma dzisiaj wielką nośność (por. Kowalewski, Piasek 2009; Pomieciński, Sikora 2009). Powinniśmy z tego faktu skorzystać, i to bez upierania się, by wybrać (moim zdaniem) mniej prestiżową nazwę - antropologię społeczną, która na dodatek często jest kojarzona z jednym z działów socjologii. Widać wyraźnie, że znów dzisiaj powracamy do koncepcji Kazimierza Moszyńskiego (1958: 60-67), głoszącej, że etnografia to przede wszystkim praca terenowa, natomiast etnologia to analityczna interpretacja konkretnych danych, a w sumie obie te strategie badawcze w połączeniu twórczym współtworzą antropologię kulturową.

Za tym podziałem idzie też silne wartościowanie, obecnie nazywać się "etnografem", to tak, jakby się samemu stygmatyzować.

Wiem z czego to wynika - w czasach profesora Moszyńskiego, ale i wcześniej, funkcjonował wyraźny rozdział między badaczami terenowymi a całą resztą. Byli zatem ludoznawcy (etnografowie) od czarnej roboty, którzy penetrowali teren i zbierali etnograficzne dane, oraz „prawdziwi” uczeni w swych akademickich gabinetach, przetwarzający fakty w uogólnienia i teorie. Dzisiaj takiego podziału nie ma. Antropolog staje się etnografem i w terenie sam zbiera dane, a następnie przekształca się w antropologa, który finezyjnie je obrabia. W takiej sytuacji nie występuje kontradykcja między niskim prestiżem kogoś, kto działa jako etnograf, a cieszącym się uznaniem analitykiem i teoretykiem, bo takiego przeciwieństwa być nie powinno. Etnografem należy być w trakcie badań terenowych, ale w tym samym czasie powinno się refleksyjnie spoglądać na przedmiot swych zainteresowań, angażując antropologiczne podejście.

Zrobię taką woltę. Profesor Anna Szyfer (2006) w książce Zapisane w pamięci parokrotnie uży wa sformułowania: „etnografem jest się cały czas”...

Tak, uważam, że tak jest. Mogę w związku z tym przytoczyć śmieszną anegdotę. W filmie Indiana Jones i świątynia zagłady jest scena, w której na dworze maharadży podają zupę, a w niej pływają oczy. Służący nabiera chochlą te oczy, a zasiadający przy stole Anglicy są w szoku. Któryś z nich zwraca się do Indiany Jonesa: „A pan nie reagujesz?”. Na to on odpowiada - „Skądże! Jestem antropologiem"3. Oczywiście takie spojrzenie na świat antropologicznymi oczami, zawsze i wszędzie, to tylko kreacja, w dodatku trudno mówić, by dotyczyła wszystkich badaczy. Niemniej antropolodzy są bardziej odporni na podobne „zdziwienia", gdyż postrzegane zdarzenia lokują w perspektywie obserwowanej kultury. To istotna cecha antropologii. Im jestem starszy, tym częściej dochodzę do przekonania, że moje postrzeganie świata (nie tylko naukowe) jest właśnie takie, a więc ukształtowane przez antropologiczne doświadczenie. Myślę, że to zjawisko naturalne i typowe dla każdej specjalności, bo trudno byłoby sobie

\footnotetext{
${ }^{3}$ Stwierdzenie takie mogło pojawić się $\mathrm{w}$ polskim tłumaczeniu, ponieważ $\mathrm{w}$ anglojęzycznej wersji dialogu Indiana Jones odpowiada: „Nic nie jest w stanie mnie zszokować. Jestem naukowcem" (Nothing shocks me. I'm a scientist). Przywołana anegdota jest złożeniem dwóch następujących po sobie scen - uczty oraz dwuznacznej rozmowy prowadzonej w komnacie towarzyszki bohatera. Odpowiedź Jonesa jest elementem wyrafinowanego i jednocześnie zabawnego flirtu.
} 
wyobrazić choćby historyka, który by z kolei nie patrzył na otaczający go świat przez pryzmat upływu czasu i dziejowych procesów.

Jednak wewnętrznie buntuję się przeciwko samemu sobie, przeciwko byciu tylko antropologiem, ponieważ uważam, że jedna dyscyplina znacznie zawęża spojrzenie. Jeżeli jesteśmy humanistami, to powinniśmy patrzeć na świat przez pryzmat różnych dyscy plin, różnych sposobów widzenia rzeczywistości, i boleję nad tym, że mimo wysiłków idących w tym kierunku nie stać nas na to, żeby to, co obserwujemy, ująć integralnie. Mam przy tym przekonanie, że spojrzenie antropologiczne nie jest spojrzeniem ani jedynym, ani najważniejszym - choć oczywiście subiektywnie jest ważne, bo to przecież moje spojrzenie. W tym sensie jestem do niego przyzwyczajony, ale nie uzurpuję sobie specjalnych praw płynących z przyjmowania właśnie tej perspektywy.

Czy nie wiąże się z tym ryzyko popadnięcia w jakiś rodzaj samozadowolenia?

Obecnie mamy nieco inną sytuację niż wtedy, kiedy byłem młodym badaczem. Wówczas dostępność światowej literatury, a także wiedzy o różnych kierunkach badań humanistycznych była bardzo ograniczona. $Z$ tego powodu, choć nie tylko, łatwo było orientować się w całokształcie krajowych nauk społecznych i humanistycznych. Sięgaliśmy często do dzieł polskich socjologów, psychologów czy filozofów - do kompendium Władysława Tatarkiewicza (1958) - szukając tam potrzebnych inspiracji. Humanistyka ogólna była w zasięgu ręki i mogliśmy się spotykać z kolegami z różnych dyscyplin, mieliśmy wspólne pola do dyskusji, ponieważ w naszej przygodzie z nauką towarzyszyły nam te same lektury. Dzisiaj jest to niemożliwe. Świadomość, że współczesna humanistyka jest tak niesamowicie rozczłonkowana, a każda dyscyplina dzieli się na ileś tam subdyscyplin, orientacji czy specjalizacji, po prostu zniewala. Bo cóż mogę powiedzieć o jakimś tam nowym nurcie filozofii - kompletnie mi nieznanym - gdy słyszę lub czytam, że jest istotny? To samo dotyczy socjologii, historii, archeologii i każdej innej dziedziny. Trudno to wszystko objąć; i dlatego towarzyszy mi przeświadczenie, że antropologia to zbyt mało, by o otaczającej mnie rzeczywistości wypowiadać się autorytatywnie i kompetentnie. Dlatego też zadziwiają mnie tacy antropolodzy, którzy, zazwyczaj bez odwołań do poważnych badań empirycznych, wypowiadają się niemal na każdy temat i to z lekkością (pseudo)naukowych celebrytów.

\section{Jest taka pokusa?}

Czy to jest pokusa? To raczej środki masowego przekazu wybierają jakiegoś człowieka - jak z tortu rodzynki - i jeśli tylko jest on chętny, by funkcjonować jako ekspert, eksploatują takiego naukowca (za jego zgodą), zadając mu pytania dalece wykraczające poza jego specjalizację. Wówczas taki „znawca” zamiast po prostu odpowiedzieć, że na ten temat niewiele ma do powiedzenia, albo że nie jest w tym zakresie kompetentny, zazwyczaj brnie dalej w takiej debacie i oczywiście rozpowszechnia albo banały, albo też mijające się z aktualnym stanem wiedzy poglądy.

\section{Presja mikrofonu.}

Przez 15 lat byłem dyrektorem Instytutu Etnologii i Antropologii Kulturowej UAM. Wielokrotnie w tym czasie dzwoniono do sekretariatu, bo akurat zbliżało 
się jakieś święto albo chodziło o „naukowy” komentarz do kolejnego wydarzenia. Dziennikarze zazwyczaj pytali: „Czy nie udzieliłby Pan wywiadu na taki lub inny temat?". Konsekwentnie odmawiałem tym propozycjom, jeżeli rozmijały się one z moimi kompetencjami, argumentując, że się na takiej to a takiej tematyce nie znam, a więc nie będę zmyślał. $Z$ reguły jednak odsyłałem dziennikarzy do innych naukowców, posiadających rzetelną wiedzę na określone zagadnienie. Są jednak ludzie, którzy poddają się tym propozycjom bardzo chętnie i wtedy przez jakiś czas są hołubieni przez mass media i, co gorsza, utwierdzają się w przekonaniu, że są faktycznie wszystkowiedzący.

W świecie, w którym trudno się wybić, zacieranie granic między dyscyplinami i udawanie kogoś, kim się nie jest, to być może sposób na radzenie sobie z rosnącą konkurencją. Zatem, czy do określenia się mianem antropologa doświadczenie terenu jest nieodzowne?

Myślę, że tak. W przeciwnym wypadku nie mielibyśmy kryteriów, które pozwalałyby powiedzieć, kto ma jakie kompetencje. Mamy bowiem wielu historyków kultury, teoretyków kultury czy kulturoznawców, od których nie wymaga się badań terenowych. Dzięki temu niektórzy z nich wygłaszają wykłady niemal na każdy temat, budząc zdumienie specjalistów mających solidne doświadczenia empiryczne. Co ciekawe, boją się zwykle przyjść do naszego Instytutu, chcą uniknąć konfrontacji ze specjalistami. Natomiast z dala od antropologów swobodnie wypowiadają się na temat przemian w Afryce, komentują problemy wielokulturowości w Kanadzie, czy też snują rozważania o problemach queer w Indiach. Zazwyczaj czynią to głównie na podstawie przeczytanych książek, wykazując tym samym znaczną erudycję. Dyskusje z nimi są zazwyczaj bezprzedmiotowe, ponieważ prowadzą zwykle do wytoczenia rozstrzygających argumentów w rodzaju: „bo przecież Bauman powiedział to a to, a inny uczony autorytet powiedział tamto". Tacy dyskutanci z trudem przyjmują do wiadomości, że może należałoby zająć się tym, co jest za przysłowiowym oknem, tym jak żyją ludzie wokół nas, w realnym świecie. Oni poruszają się w innym typie rzeczywistości: takiej, którą poznaje się poprzez lektury i wypowiedzi autorytetów. Spoglądają na otaczający ich świat nie bezpośrednio, własnymi oczyma, ale poprzez poglądy uznanych i modnych uczonych. I co istotne, nie przekraczają tej granicy. Sądzę, że nawet nie chcą jej przekroczyć. Ciekawe byłoby zbadanie ich mentalności - dowiedzenie się, dlaczego nie chcą tego kroku uczynić. Czy boją się konfrontacji z prozą życia, czy też uważają, że tą drogą nie dotrze się do niczego ciekawego poznawczo? Może sądzą, że jeśli ludzie zachowują się inaczej, niż założyli to i opisali myśliciele $\mathrm{z}$ "pierwszej ligi”, to musiałoby to świadczyć albo o słabości konstrukcji wymyślonych przez autorytety, albo też o tym, że obserwowani ludzie zachowują się lub myślą niezgodnie z założonymi uprzednio standardami, podważając tym samym obowiązujące poglądy.

Tu leży sedno problemu współczesnej antropologii, jeśli chodzi o jej oddziaływanie i społeczną rolę. Inni badacze kultury „sprzedają się" zdecydowanie lepiej, z większą łatwością. Czynią to bez żadnych zahamowań - przeczytają kilka książek i jeśli mają dobrą pamięć i umiejętności erystyczne, to potrafią błyszczeć 
niczym wybitni myśliciele. Ktoś, kto specjalizuje się choćby w badaniach Podhala, nie będzie się wypowiadał na temat Warmii i Mazur, bo niewiele na ten temat wie i w pełni zdaje sobie z tego sprawę. Wszystkowiedzący specjaliści wypowiadają się natomiast na każdy temat. Jest to spory problem dla antropologii, z czym zgadzają się nasi koledzy i w kraju, i na świecie. Wszyscy wylewają te same łzy, czy rzucają kalumnie na - nazwijmy to - „pseudoantropologów”. Widać to z reguły na międzynarodowych konferencjach, gdzie co najmniej połowa referatów odpowiada antropologicznej dyscyplinie i jest oparta na własnych badaniach prelegenta, zaś druga połowa to wystąpienia z gatunku „bo trzeba było jakiś referat zaprezentować". Jest konferencja, powiedzmy, o problemie rasy, to...

\section{...zostaję specjalistą od rasy.}

Autorzy takich wystąpień myślą sobie: „To może wezmę na warsztat jakiegoś badacza lub pisarza i przeanalizuje, jak on podchodził do problemu rasy?". I wygłaszają bardzo „interesujący” referat.

\section{Po co to komu?}

To już inne pytanie. Proszę zobaczyć, obecnie literaturoznawcy przekształcają się w kulturoznawców. To masowy trend. Bo ile można pisać dywagacji na temat znanego poety czy pisarza? W tym zakresie możliwości poznawcze są dość ograniczone. Tymczasem my, antropologowie, jako badacze zarówno dawnych, jak i aktualnych form kulturowych, mamy znacznie lepsze, bo niemal nieograniczone, możliwości poznawania nowych obszarów. Oni wyraźnie mówią: "Jesteśmy teraz interpretatorami kultury". Trudno to określić jako antropologię kulturową, to raczej zbliża ich do antropologii kultury. Tę perspektywę można ewentualnie traktować jako subdyscyplinę, w ramach której badacz interpretuje twory kultury rozumianej zwykle przez duże „K" - zajmując się filmem, literaturą czy mediami. Jest to równoznaczne z patrzeniem na rzeczywistość przez pryzmat tychże wytworów artystycznych czy medialnych. Jest to uprawnione działanie, którego nie wartościuję. Być może dzięki temu antropologia staje się coraz bardziej znana, ale już nie jako odrębna dyscyplina, lecz jako atrakcyjne podejście badawcze. Granice poszczególnych dyscyplin zacierają się i można co najwyżej antropologizującym kolegom z innych dyscyplin humanistycznych i społecznych zarzucić braki warsztatowe. Trzeba jednak rzeczy nazwać wprost - taki trend to banalizacja antropologii (por. Robotycki 1995). Poprzez tego rodzaju tendencje antropologia staje się modna jako dyscyplina objaśniająca świat człowieka, równocześnie ulega banalizacji, w jej wyniku każdy w zasadzie może być antropologiem, powołując się na antropologiczne autorytety, co oczywiście w żadnej mierze nie oznacza, że osoba taka jest $\mathrm{w}$ istocie profesjonalnym antropologiem.

\section{I świetnie się sprzedaje.}

Czasem zdarza się, że podczas spotkań towarzyskich rozmówcy dowiadują się, że jestem antropologiem, że znam te same rejony świata, które odwiedzają trawelebryci. Zawsze wtedy pada pytanie, czy potwierdzam te popularne relacje. Zbijam wówczas ludzi z pantałyku, mówiąc, że to kompletne bzdury. Indianie nie chodzą w strojach "tradycyjnych" i nie polują na węże. To tak, jakby w jakiejś zachodniej gazecie opublikowano zdjęcia przedstawiające współczesną polską 
wieś, a w niej drabiniaste wozy i pielgrzymów przy przydrożnych krzyżach. Rozmówcy nie chcą mi zazwyczaj wierzyć i rozmowa momentalnie gaśnie. Zdaję sobie sprawę, że w ich oczach uchodzę pewnie za zazdrośnika, o którym myślą: „Ten facet jest po prostu zawistny, bo on nie jest tak znany i nie występuje publicznie". To nieporozumienie świetnie odkłamuje książka Podgladając Innego (Gawrycki 2011). Jej autor, Marcin Gawrycki, zmierzył się z medialnymi autokreacjami takich osób, jak Beata Pawlikowska, Martyna Wojciechowska czy Wojciech Cejrowski. Zdekonstruował sens ich działań w Polsce, pokazując, że zamiast informować społeczeństwo o odległych kulturach, to utwierdzają stereotypy, $\mathrm{w}$ niczym nie zmieniając naszego oglądu świata zewnętrznego.

Związki z mediami bywają trudne. $Z$ jednej strony pojawia się bowiem pokusa "gwiazdorzenia", a drugiej zaś strony mamy do czynienia z kompletną nieobecnością antropologii i jej znikomą rozpoznawalnością. Przed dekadą, w debacie poświęconej antropologii zaangażowanej toczonej na łamach „(op. cit.,)", pojawiały się głosy dotyczące tak kłopotliwej sytuacji. Agnieszka Kościańska (2004: 13) apelowała, by „wprowadzić rodzimą antropologię w krąg międzynarodowej debaty oraz, co ważniejsze, w rodzimy dyskurs publiczny, uczynić z niej część krytyki społecznej". Michał Buchowski (2005: 6) tłumaczył takie położenie niewielką liczebnością środowiska antropologów i odgrywaniem roli ekspertów głównie przez socjologów.

Takie ujęcie sprawy nie dotyka istoty problemu. Co najwyżej wskazuje na niewielką obecność dyscypliny w debacie publicznej, a ta nie ma - według mnie wielkiego znaczenia. Patrząc pragmatycznie, to, czy dana dyscyplina ma znaczenie społeczne, wynika z faktu, czy jej tezy mogą być przekute na praktykę. Jeśli więc polska antropologia w naszych krajowych warunkach nie ma zbyt dużego obszaru praktycznego zastosowania, to w tej sytuacji możemy sobie tylko na ten temat ponarzekać, ale jej pozycji nie zmienimy.

Zdecydowana większość antropologów pracujących w Ameryce Łacińskiej działa w obszarze antropologii stosowanej, i gdy się tam pojawiam, jestem trochę traktowany jak dziwoląg, podobnie zresztą jak i inni Europejczycy czy Amerykanie, którzy przyjeżdżają tam głównie po to, aby zebrać potrzebne informacje i po zakończeniu badań wyjechać do swych rodzimych krajów. Jako antropolog, nazwijmy to - akademicki, w Peru czy Boliwii zwykle napotykałem kłopoty. Gdy tylko pojawiałem się $\mathrm{w}$ terenie, pierwsze pytanie miejscowych brzmiało: „Po co przyjechałeś? Co nam dasz? My z tobą będziemy rozmawiali, ale o co chodzi? Przywiozłeś nam pieniądze, a może mi kupisz rower, a może samochód?". Albo: „No dobrze, a co ty chcesz zrobić tutaj dla nas?”. Odpowiedź, że „nic konkretnego" poza zbieraniem informacji i poznawaniem ich sposobu życia spotykała się zwykle z niedowierzaniem.

U tamtejszych mieszkańców wizja antropologa opiera się na oczekiwaniu, że jest on dostarczycielem jakiś dóbr lub środków, bo antropolog kojarzy im się z kimś, kto pracuje na rzecz jakiejś organizacji pomocowej, agencji rządowej czy Banku Światowego. Przeważnie tylko z takimi ludźmi się stykają. Więc jeżeli przybywa antropolog, za którym nie stoi żadna organizacja i nie przywozi ze sobą 
większych pieniędzy, a co najwyżej tylko dzieciom rozdaje cukierki, to tubylcy uznają, że nie mają w zasadzie, o czym z tobą rozmawiać. Nie jesteś dla nich wartościowym partnerem.

Wracając do wcześniejszego tematu, rezultat jest taki, że polscy etnologowie/ antropologowie mogą sobie mówić o tym, że chcą uprawiać naukę stosowaną, ale najpierw musieliby udowodnić, że są w stanie ten założony cel osiągnąć. Jak to uczynić? Socjologia próbowała to robić znacznie częściej, a mimo to rezultat okazał się opłakany. Z jednej strony jawi się ona jako dyscyplina oderwana od rzeczywistości i zanurzona w czystej teorii społecznej: zgłębiając, „,co powiedział Weber" czy "co myślał Habermas”. Na rynku pracy tego rodzaju dywagacje nie mają wielkiego znaczenia. $Z$ drugiej strony praktyczna socjologia dzisiaj to przede wszystkim badania marketingowe i pomiary nastrojów politycznych. Znaleźli się zatem i oni między dwoma ścianami: między gimnastyką teoretyczną z historii myśli społecznej a wąskim doradztwem.

Nie jestem zwolennikiem tego, byśmy poszli w podobnym kierunku, znaczyłoby to, że antropolog staje się doradcą od rzeczy banalnych. Tymczasem z pewnością są istotne pola, na których możemy działać; otwarte pozostaje tylko pytanie o status dyscypliny. Tak zwani antropologowie stosowani, w tym także ci, którzy pracują komercyjnie na rzecz instytucji, firm, agencji, są innymi specjalistami niż badacze uniwersyteccy. Nie wnoszą wiele do nauki, a to, że się określają tak samo, nie znaczy, że robią to samo.

To tak, jak z różnicą między specjalistą studiującym trendy światowe w przepływach kapitałów a tym, który pracuje w banku. Dlaczego mamy zarzucać temu, który śledzi makroekonomiczne tendencje, że nie wdraża swoich ustaleń w życie? On jest naukowcem analitykiem, ale bez tych analiz praktycy byliby jak dzieci we mgle. Właśnie taka jest antropologia w krajach Zachodu czy w Ameryce Łacińskiej. Studenci są tam szkoleni przede wszystkim po to, by po studiach pracować $\mathrm{w}$ organizacjach pomocowych, w agencjach rządowych, w urzędach zajmujących się mniejszościami, ludnością tubylczą czy zmarginalizowaną. Są do tych zadań przygotowywani przez tych, którzy są naukowcami akademickimi. $\mathrm{Ci}$ akademiccy antropologowie tą praktyczną sferą antropologii się nie zajmują bezpośrednio, bo ona ma nikły wpływ na rozwój nauki, za to może mieć znaczny wpływ na nasze codzienne życie.

To jest ten kolejny dylemat. Bo co zrobić, jeżeli coś nie rozwija danej nauki, ale jest jednocześnie pożyteczne? W Ameryce Południowej antropologia została uznana za dziedzinę, która szkoli specjalistów w zakresie pracy doradczej i eksperckiej. Tak jak fizyk, który pracuje w laboratorium na terenie uczelni, tak ja jadę $\mathrm{w}$ teren, do organizacji indiańskich, i badam, jak one wpływają na kształtowanie lokalnej polityki. Nie zamierzam im doradzać $\mathrm{w}$ tej materii, bo oni mają lepszych doradców, poza tym wówczas musiałbym przejść na inną stronę, sam opowiadając się aktywnie po jednej z nich.

W takich warunkach położenie antropologa nie jest zbyt jasne i oczywiste, $\mathrm{w}$ dodatku bardzo trudno je wytłumaczyć miejscowym. Powoływanie się na motywacje intelektualne, takie jak chęć poznania ich sposobu życia czy napisania 
książki, są bezskuteczne. Czasami jednak zdarzają się sytuacje odmienne, tak jak $\mathrm{w}$ trakcie mojego pobytu badawczego w Chile. Po raz pierwszy przebywałem $\mathrm{w}$ kraju, w którym to, że nie byłem antropologiem stosowanym, działało na mają korzyść. Indianie antropologów tam nie poważają, i to właśnie za to, że przeważnie są oni antropologami stosowanymi. $W$ ich mniemaniu antropolog to taki człowiek, który przybywa z jakąśs konkretną misją, jest wynajęty przez jakąś korporację albo przez jakąś agencję pozornie naukową i neutralną. Później jednak okazuje się, że jego obecność w terenie jest związana z planowaną inwestycją mogącą nie być po myśli tubylców. Jeśli nawet nie ma o tym mowy, to Indianie zwykle uważają, że w związku z prowadzonymi badaniami władze mogą zebrane dane wykorzystać niekoniecznie w interesie tubylców. Bardzo często antropologowie stosowani sami nie mają najmniejszego pojęcia, po co i dla kogo tak naprawdę wykonują zlecone badania. Często też się zdarza, że są to badania robione pro forma. Tak jak w przypadku wynajętych ekologów, którzy mają stwierdzić autorytatywnie, że na danym terenie nie ma gatunków chronionych, i wydać werdykt umożliwiający rozpoczęcie budowy autostrady. W podobnym celu wysyła się także antropologów - mają oni zbadać, ilu na danym obszarze żyje Indian, aby te dane móc następnie przekazać swym mocodawcom planującym tam inwestycje. Przychodzą do osady i rozmawiają z mieszkańcami: „Dzień dobry. Pani tu mieszka?". „Tak, mieszkam tu”. „A z kim?”. „Z córką”. „A jak córce na imię?”. „Eliza”. „A kto tu jeszcze mieszka?”. Spisują te rodziny, robią im zdjęcia, po powrocie przygotowują raport, stwierdzając, że na wskazanym terenie mieszka, powiedzmy, sześć rodzin. Z nich trzy uważają się za Indian, a pozostałe tak się otwarcie nie identyfikują, choć nie wiadomo, kim w rzeczy samej są. Te dane służą następnie decydentom, którzy wyciągają następujące wnioski: „A więc nie ma problemu, bowiem połowa mieszkańców to nie są Indianie; a zatem mamy do czynienia z populacją «mieszaną etnicznie», co sprawia, że nie obejmuje jej ochrona zagwarantowana dla ludności rdzennej". Wiadomo - Indianie zwykle zdecydowanie protestują, gdy czują się zagrożeni, pozostali nie mają takiej sprawczości, bo po prostu nie mają się do kogo odwołać. To jeden z takich przykładów, z którym sam się spotkałem w terenie, dość banalny, bywają i bardziej drastyczne. $Z$ tych względów antropolodzy są tam niezbyt dobrze widziani.

Jakie powinności stoją przed antropologią jako dyscypliną, gdy spojrzeć na nią jak na naukę stosowaną?

Nie czuję się misjonarzem. Absolutnie nie. Jestem przeciwnikiem ideologizacji nauki, co nie oznacza, że nie dostrzegam jej oddziaływania. W związku z tym nie uważam, żeby jakakolwiek nauka miała swoją „misję specjalną” do spełnienia. Nie po to uprawiamy naukę, aby być misjonarzami. Gdybym chciał nim być, to poszedłbym do seminarium albo stał się politykiem lub społecznym aktywistą. Możemy zatem zadać pytanie: jakie zadania antropologia ma do wypełnienia? Powinna zająć się tym, czego nie wykonają inne dyscypliny, i powinna swe zadania zrealizować porządnie. Ponieważ stale pojawiają się nowe pulsujące energią sytuacje kulturowe, zadaniem antropologów powinno być ich badanie. Nie mogę się jednak zgodzić z tymi, którzy twierdzą, że antropologia powinna 
zajmować się wyłącznie współczesnością. Oczywiście bieżący strumień życia jest głównym nurtem refleksji antropologicznej i z pewnością na nim powinniśmy się w większości skupić.

To jednak nie znaczy, że nie należałoby co jakiś czas wracać do klasycznych tematów. Uważam antropologię za jedną z dyscyplin podstawowych w ramach nauk społecznych i humanistycznych, która ukazuje nam różnorodność otaczającego nas świata, a zarazem ułatwia jego rozumienie. Taka perspektywa to wspaniała rzecz. Jeśli chodzi natomiast o górnolotne stwierdzenie, że antropologia ma jakąś specjalną misję do spełnienia, to wątpię. Antropologia jako nauka jest coraz bardziej doceniana, i to bez jej zaangażowania "misyjnego".

\section{Jak w takim razie sytuować głosy dotyczące zaangażowania?}

Są antropologowie zaangażowani i są antropologowie niezaangażowani. To jakby dwa plemiona. Ci pierwsi twierdzą, że czują dyskomfort wówczas, gdy uświadamiają sobie, że ich działalność naukowa, a przede wszystkim to, co piszą, nie ma jakiegoś bezpośredniego przełożenia na życie ludzi. Wydaje się, że niemal każda dyscyplina ma te dwa aspekty. Jeśli wszyscy byliby zaangażowani w praktykę, to pewnie nikt by nie rozwijał tych dziedzin, które nie mają pozornie (i dzisiaj) żadnego bezpośredniego związku z otaczającą nas rzeczywistością, a badania z zakresu teoretycznego nie miałyby powodzenia. Nie ma żadnego dowodu wskazującego na to, że antropologia zaangażowana, socjologia zaangażowana albo fizyka aplikacyjna rozwijają daną dyscyplinę w większym stopniu niż jej wersja niezaangażowana. Jasne jest, że obok teoretyków i badaczy spraw pozornie oderwanych od praktyki potrzebujemy naukowców, którzy potrafią wdrażać te treści w nurt bieżącego życia. Mogą to czynić w sposób fachowy, zgodny z regułami etyki, aplikując swoją wiedzę antropologiczną do systemów edukacji wielokulturowej, programów polityki etnicznej, strategii zarządzania korporacjami czy optymalizacji administracji w samorządach. Obszar tych możliwości jest ogromny i stale się poszerza.

Ja natomiast - tak jak wspominałem - nie przynależę do tego „wdrożeniowego" klanu. Przede wszystkim zajmowałem się badaniami oraz dydaktyką akademicką, co nie oznacza, że dezawuuję antropologię stosowaną. Mam za to silne przeświadczenie, że w gruncie rzeczy trudno spotkać znanych antropologów, którzy byliby najpierw bardzo głęboko wkomponowani w sferę antropologii zaangażowanej, a potem powróciliby do antropologii akademickiej i w jej ramach odnosili sukcesy. Raczej spotykamy odwrotne zjawisko; tylko że w takich przypadkach mamy zazwyczaj do czynienia z antropologami wysokiej klasy, którzy rzucają pewne śmiałe pomysły (w ramach action anthropology) - formułują wskazówki, co i jak należy robić, a inni badacze praktycy ich postulaty wdrażają i monitorują. W tym sensie naszym obowiązkiem jest nie tylko stałe wzbogacanie zasobu wiedzy, ale także poszerzanie możliwości praktycznej strony antropologii. Nie widzę tej sytuacji jako alternatywnej, funkcjonującej na zasadzie „albo-albo", a raczej przeciwnie, jako komplementarne, wzajemnie dopełnianie się. 
Wydaje się, że zajmowanie się tak bardzo różnymi formami antropologii wymaga odmiennych kompetencji. Jakie zatem cechy bądź predyspozycje powinny mieć osoby zajmujące się antropologią?

Wszystko zależy od rodzaju uprawianej antropologii. Uważam, że nie znajdziemy w tym przypadku zestawu uniwersalnych cech, bo przecież inne przymioty są potrzebne do pracy w muzeum, a inne w działalności akademickiej, a jeszcze inne do aktywności doradczej czy eksperckiej w sprawach migracyjnych czy konfliktów etnicznych. Zupełnie inny profil jest wymagany od badacza zgłębiającego teoretyczne podstawy zmiany kulturowej niż od etnografa terenowca, który to musi być nie tylko odporny na trudy podróży, lecz powinien także odznaczać się psychologiczną otwartością na Innego. A więc tutaj nie ma i nie może być jednej odpowiedzi, ponieważ antropologia jest niezwykle różnorodna. Z pewnością formowanie adeptów antropologii powinno polegać na tym, aby $\mathrm{w}$ analizowanych procesach, zjawiskach, wydarzeniach i konfliktach dostrzegali oni na pierwszym planie znaczenie wzorców kulturowych, elementów dziedzictwa kulturowego, ciążenia tradycji, ścierania się odmiennych wartości i wizji świata. Chodzi o to, aby te aspekty znalazły się w centrum ich uwagi. Oczywiście antropologowie nie mają na badanie tych kwestii monopolu. Takie jednak podejście jest (powinno być) dla antropologów charakterystyczne. Nie oznacza to jednak, że każdy antropolog w równym stopniu respektuje te zasady. Jedni są na nie bardziej wyczuleni, inni próbują je skrzyżować z regułami obowiązującymi w pokrewnych dyscyplinach, jeszcze inni dość daleko od nich odchodzą. Mamy tutaj całe spektrum rozmaitych podejść, co z kolei przekłada się na bardzo duże zróżnicowanie środowiska. W rezultacie to, co nazywamy kształtowaniem się jednolitego etosu naszej dyscypliny, jest dosyć iluzoryczne.

Czy znaczyłoby to, że w przypadku etnologów bądź antropologów w ogóle nie można mówić o etosie zawodowym jako takim?

Mimo tych wątpliwości myślę, że jest coś takiego jak etos antropologa, w każdym razie chciałbym, żeby on istniał. Jestem pewny, że wielu antropologów podziela mój pogląd. Osobiście sądzę, że etos ten jest obecny przede wszystkim u tych, którzy w swym zawodowym doświadczeniu przeszli przez trud badań terenowych. Mam natomiast wątpliwości, czy jest on obecny u badaczy niemających tego rodzaju doświadczenia. Można bowiem zadać sobie pytanie, czym zatem różnią się oni od pozostałych badaczy zajmujących się studiami nad kulturą? To, że ktoś identyfikuje się sam jako „antropolog", jeszcze niewiele znaczy, podobnie jak i to, że często powołuje się na autorytety i teorie antropologiczne. Tymczasem ci, którzy stykają się bezpośrednio z trudami i specyfiką badań terenowych, kontaktują się poza murami uczelni z innymi ludźmi, już jako studenci kształtowani są jako osoby, które nabywają umiejętności obserwacji, dociekliwej konwersacji, przełamywania barier, uczą się szacunku wobec swych rozmówców, a także odpowiedzialności za tak kształtowaną relację ze swoimi informatorami, a w zasadzie partnerami. Nie chcę powiedzieć, że się utożsamiają ze swymi 
rozmówcami i gospodarzami ${ }^{4}$, bo nie powinni tego czynić, ale to doświadczenie terenowe silnie formuje badacza, $\mathrm{i}$ to na całe życie. Nie jest to praca $z$ tekstem w zaciszu biblioteki, ale prawdziwe spotkanie z żywym człowiekiem, od którego oczekujemy, że wprowadzi nas w nieznany nam bliżej świat jego wyobrażeń. Często to głębokie wejście w badane środowisko zmienia także dosadnie antropologa, który przyjmuje postawę rzecznika czy adwokata badanej grupy. Rozumiem ten proces $\mathrm{w}$ sensie psychologicznym, a w pewnych sytuacjach podzielam taki pogląd, ale nie mogę się zgodzić z tezą, że antropolog w każdej sytuacji powinien być adwokatem swych terenowych partnerów. Antropolog w relacjach osobistych ze swą grupą w terenie musi kierować się szacunkiem, zrozumieniem i odpowiedzialnością za swe czyny i słowa. Jeśli chce, może być ich adwokatem, rzecznikiem czy doradcą, ale musi zdawać sobie sprawę, że wówczas wkracza na bardzo grząski lub/i delikatny grunt, na którym to role badacza, adwokata i reprezentanta jednej strony zaczynają ulegać zatarciu. Kilkakrotnie sam znalazłem się w zbliżonej sytuacji i muszę stwierdzić, że nie były to proste doświadczenia, a ich konsekwencje odzwierciedliły się albo w zmianie relacji z badanymi ludźmi, albo też w sposobie (nie)wykorzystania uzyskanych informacji.

Kwestia wyboru stanowi zatem delikatną granicę. Miałem z tym dość często do czynienia wtedy, kiedy studenci proponowali mi kierowanie pracami magisterskimi dotyczącymi takich grup społecznych, których sami byli zaangażowanymi członkami. Nie jestem temu zbyt przychylny, bo wiem, że mogę mieć z nimi poważny kłopot. Jako początkującym i niedoświadczonym badaczom będzie im trudno wyzwolić się ze swojego własnego uwikłania w daną grupę. Z reguły właśnie z tego powodu albo ich namawiam na realizację innego tematu, albo też rezygnuję z prowadzenia tego typu prac. Odmawiam, ponieważ uważam, że będzie mi bardzo trudno kogoś takiego właściwie prowadzić, by wytworzyć u takiego studenta pewnego rodzaju podejście czy osobowość „schizofreniczną", dzięki której taka osoba w trakcie zbierania materiałów i ich analizy będzie wnikliwym badaczem, antropologiem, a w pozostałym czasie będzie zaangażowanym członkiem takiej grupy. Wbrew pozorom są to bardzo poważne problemy.

Wracając do istoty pytania, jako antropolodzy uprawiający terenową etnografię, niezależnie od tego, gdzie spotykamy ludzi, którzy nas interesują w prowadzonych badaniach, z jakichkolwiek by oni byli kultur, ras czy narodów, to znajdujemy z nimi znaczny stopień wspólnoty. Żyjemy wśród nich, pracujemy na ich terenie dzięki ich pomocy i zaufaniu, zbliżamy się do nich, poznajemy ich codzienne troski. To wyposaża nas w szczególnego rodzaju doświadczenie, które z kolei w znacznym stopniu waży na sposobie uprawiania antropologii i postrzegania otaczającego świata.

Zwrócił Pan uwagę na wartość, jaką w antropologii stanowi budowanie relacji międzyludzkich. Czy w Pańskiej praktyce kontakty z ludźmi należącymi do innych kultur stanowiły jakiś problem?

\footnotetext{
${ }^{4} \mathrm{Na}$ temat utożsamiania się (going native) z badanymi, na przykładzie Franka Hamiltona Cushinga, pisał Bartłomiej Walczak (2009).
} 
W sensie psychologicznym dobrze sobie radzę w takich sytuacjach, niezależnie od tego, kim są ci ludzie i do jak odległej bądź bliskiej kultury przynależą. Staram się w każdej sytuacji być antropologiem i jako tak ukształtowany badacz postrzegać otaczającą mnie rzeczywistość. Jednak nie wykorzystuję czasu wolnego do jakichś zabaw antropologicznych w rodzaju prowadzenia pseudowywiadów, choćby podczas jazdy pociągiem, tylko dlatego że coś mnie szczególnie zainteresowało (por. Paluch 2012: 46-49). Mogę siebie ocenić właśnie w ten sposób, bo nie napotykam istotnych trudności w nawiązywaniu kontaktów, potrafię to robić, pewnie coraz lepiej - tak mi się wydaje. Zdaję sobie jednak w pełni sprawę z własnych ograniczeń. W terenie staram się sam siebie kontrolować, ale nie znaczy to, że nie jestem tym zadaniem skrępowany. To uczucie towarzyszy mi systematycznie. Wiem, że jestem intruzem, mam pełną tego świadomość, czuję w związku z tym dyskomfort, ale to są moje wewnętrzne, głęboko skrywane uczucia. Wiem, że niepokoję ludzi, że zabieram im czas, że chcę coś od nich uzyskać, co jest potrzebne do wykonywanego przeze mnie zadania. Zdaję sobie sprawę, że występuję niejako w podwójnej roli - badacza i jednocześnie zwykłego przybysza z innego świata, a więc występuję jako ktoś z zewnątrz, kogo się przyjmuje jak gościa, częstuje maślanką, zupą czy alkoholem. Wiem, że zrozumienie tego, kim jestem, czym się zajmuję, nie może być pełne u tej drugiej strony. Takie relacje są zawsze nieco zagmatwane, nieostre. Pewnie dlatego Amerykanie tak często decydują się płacić informatorom. Są to zazwyczaj grosze, ale zmieniają one typ relacji i ustawiają ją na płaszczyźnie rynkowej usługi. Nie aprobuję takich praktyk w żaden sposób.

Zrozumiałem to dopiero wtedy, kiedy sam się z takim zjawiskiem bezpośrednio zetknąłem. Okazuje się, że nie chodzi wcale o pieniądze. Amerykanie kupują sobie... czy raczej likwidują w ten sposób swój dyskomfort. Wchodzą w inny typ relacji. Prowadząc wywiad, cały czas usilnie się staram, aby utrzymać dobrą relację z moim interlokutorem, by w żaden sposób nie znudzić go albo nie obrazić jakimś niestosownym gestem czy zachowaniem. Muszę być miły, sympatyczny, a jednocześnie spięty i uważny, skoncentrowany na moim zadaniu. Po takim wywiadzie jestem zwykle bardzo zmęczony. Po pierwsze, z powodu konieczności merytorycznego prowadzenia rozmowy; po drugie, sam siebie muszę stale kontrolować; po trzecie, prowadzę jednocześnie dyskurs towarzyski, i to zazwyczaj w obcym języku. To angażuje nieprawdopodobnie, i po skończonym wywiadzie czuję znaczne zmęczenie, ale też satysfakcję, że udało się wszystko pomyślenie doprowadzić do końca, że sprawa nie jest zamknięta, że mogę do tej osoby jeszcze wrócić, że rozstaliśmy się w miłej atmosferze. Tymczasem Amerykanie kupują sobie - właśnie! - inną relację; relację o charakterze biznesowym: angażuję ciebie, dostajesz 10 dolarów, jesteś do mojej dyspozycji, a więc nie ma żadnych niedomówień między nami. Lubię jeździć na badania terenowe, jestem pełen ekscytacji, gdy wyruszam w podróż, natomiast wracając z badań, cieszę się, że już po wszystkim, i mogę teraz być tylko sobą, bez konieczności stałej mobilizacji. W terenie sytuacja jawi się inaczej, człowiek jest sobą jako osoba o określonej konstrukcji psychicznej, jest badaczem - antropologiem, jest „obcym” wśród tubylców, i do 
tego jest jeszcze w pewnym sensie aktorem starającym się tworzyć jak najlepsze relacje. To jest bardzo ciężkie i wyczerpujące zadanie.

\section{Gdzie leży źródło wspomnianej ekscytacji?}

Przede wszystkim w spotkaniu z ludźmi, których nie znam. Nie myślę wtedy stale o konkretnym celu naukowym. Oczywiście on istnieje i jest ważny, przejawia się choćby w sposobie zadawania pytań, bo to przecież wypadkowa tego celu, ale rozmowa jest dla mnie sama w sobie wartością. Ludzie otwierają się przede mną, i im bardziej udaje mi się przełamać naturalny dystans, tym większe mam poczucie satysfakcji, bo czuję że moi rozmówcy zaczynają mi ufać - mam wtedy takie wewnętrzne przeświadczenie, że daję sobie radę.

Od 2008 r. prowadziłem badania w południowym Chile wśród Mapuczy (por. Posern-Zieliński 2010-2011, 2011, 2012). Chilijscy antropolodzy jeszcze przed rozpoczęciem mojego projektu mówili mi: „Zapomnij o tych badaniach. To w ogóle jest niemożliwe. Po pierwsze, jesteś u nas za krótko; po drugie, Mapucze są nieufni i trzeba bardzo długo wchodzić w ich środowisko". Rzeczywiście, my jako antropolodzy z Europy, a więc z zewnątrz, z innego świata, jesteśmy zawsze pod presją tego, że przyjeżdżamy na stosunkowo krótki okres i po wykonaniu zadania szybko wyjeżdżamy. Nie zawsze możemy sobie pozwolić na badania stacjonarne albo na takie, kiedy to w teren wyjeżdża się regularnie co tydzień lub co miesiąc, opuszczając na krótko obowiązki uczelniane. A właśnie tak postępują tamtejsi antropolodzy. Dla nas koszt wyjazdu za ocean jest bardzo wysoki, zwykle możemy sobie pozwolić co najwyżej na dwu-, trzymiesięczny pobyt. Trzeba więc na miejscu maksymalnie wykorzystać ten czas i każde niezbyt udane spotkanie może być uznane za czas stracony, świadomość tego towarzyszy nam nieustanne. $W$ takim scenariuszu bardzo trudne jest familiaryzowanie się z lokalną społecznością i stopniowe wchodzenie do niej, czyli to, co chilijscy badacze czynią latami; mają już swoich głównych informatorów, znają ich bardzo dobrze, dzięki nim nawiązują kontakty z nowymi ludźmi. Tymczasem sytuacja badacza z Polski czy innego kraju Europy rodzi poważne dylematy, bo przybywa się z całkiem innego kręgu kulturowego, nie zna się lokalnych kontekstów, słowem nie zna się niemal niczego. Na domiar złego można się spotkać także z innym nieoczekiwanym czynnikiem, gdy okazuje się na miejscu, że tubylcy bardzo źle postrzegają antropologów, uważając, że taki badacz nie jest po ich stronie, że może pracować dla wrogich im sił, przykładowo dla opresyjnego względem nich państwa lub międzynarodowej korporacji.

W takiej sytuacji wszystko jest przeciwko mnie, i to, że jestem antropologiem, i to, że jestem cudzoziemcem, i to, że przyjeżdżam z innego świata, i to, że nie mam czasu na stopniowe wchodzenie w lokalne środowisko, a także i to, że nie znam specyfiki badanego terenu. W związku z tymi potencjalnymi przeciwnościami obrałem strategię, która okazała się bardzo udana i satysfakcjonująca. Wpadłem na pomysł pracy z asystentami terenowymi, których rekrutowałem z grona lokalnych Indian. Znalazłem takich ludzi, przy czym miałem wielkie szczęście, bo nie była to kwestia systematycznego rozeznania, ale w zasadzie szczęśliwego przypadku. W moich badaniach wspomagały mnie dwie osoby, 
które okazały się świetnymi badaczami terenowymi - jedna z nich była absolwentem antropologii, a druga - kimś w rodzaju społecznego aktywisty. Tak się złożyło, że ci asystenci wywodzili się z bardzo szacownych rodzin mapuczańskich, mieli rozliczne kontakty osobiste, dzięki którym legitymizowała się szybko moja obecność w terenie. Dodatkowo osoby te były aktywistami współczesnych rewindykacyjnych ruchów i organizacji indiańskich. W terenie pracowaliśmy zatem zawsze parami. To było dla mnie całkowicie nowe doświadczenie pracy terenowej. Zanim gdziekolwiek wyruszałem, asystenci przygotowywali grunt: po pierwsze, szukali odpowiednich do tematyki badań informatorów; po drugie, wyjaśniali tym ludziom, kim jestem, czego chcę i z jakiego powodu do nich przyjechałem. To miało ogromne znaczenie, ponieważ przyjmowano mnie wtedy z ogromną dozą zaufania i otwartością. Przede wszystkim nie byłem postrzegany jako osoba z niechętnego im środowiska, czyli z kręgów chilijskiej władzy. Dzięki temu powstały optymalne warunki dla prowadzenia badań terenowych.

W rozmowach z Mapuczami brali udział pomagający mi asystenci. Wiedzieli, o co mi chodzi, i kiedy dostrzegali moje naturalne zmęczenie, przejmowali dalsze kierowanie rozmową. Co ciekawe, asystenci ci w ogóle nie uczestniczyli w wywiadach z ludźmi spoza środowiska indiańskiego (urzędnikami czy różnymi chilijskimi oficjelami). Nie chcieli mi w żaden sposób pomagać w tym zadaniu. I słusznie! Jak się zorientowałem - nigdy mi tego nie powiedzieli, bo to byłoby dla nich przykre - moje kontakty z Chilijczykami były znacznie bardziej efektywne i "otwarte” ze względu na mój status cudzoziemca. W kontaktach z władzami, $\mathrm{w}$ rozmowach prowadzonych w urzędach, agencjach, szkołach to ja bez udziału tubylczych asystentów grałem „pierwsze skrzypce”. Dzięki temu podziałowi obowiązków świetnie się nawzajem uzupełnialiśmy. Każdy wiedział, gdzie jest jego miejsce, jakie ma zadania. Niewątpliwie był to trochę nietypowy sposób prowadzenia badań. Byłem zachwycony tym nowym doświadczeniem, choć muszę przyznać, że przez to byłem jeszcze bardziej zmęczony po każdym dniu pracy. W tym bowiem przypadku dochodziła do moich zadań antropologicznych jeszcze jedna dodatkowa funkcja - nie tylko tego, który przeprowadza wywiady, lecz także badacza, który w jakiś sposób musi kontrolować poczynania asystenta.

I pilnować tego, żeby w jakiś sposób nie doszło do pomieszania wyznaczonych ról.

Mało tego; nie mogłem pozwolić na to, by asystenci po zakończeniu wywiadu rozchodzili się. Oni mieli jeszcze jedno bardzo ważne zadanie. Otóż byli pierwszymi komentatorami i interpretatorami tych wywiadów. Te komentarze miały dla mnie taką samą wartość jak wywiady. Pochodziły z tego samego środowiska etnicznego, choć oczywiście były już rodzajem metakomentarza. Tym bardziej, że były to opinie o ich rodakach. Do tego trzeba dodać, że mieszkałem z moimi asystentami pod jednym dachem, co pozwalało mi również na prowadzenie z nimi długich konwersacji. Z asystentami rozmawiałem o wszystkim - o ich poglądach politycznych, o tym co myślą o osobie, z którą wcześniej prowadziliśmy wywiad; rozmawialiśmy o wielu interesujących sprawach, jadąc do domu informatora czy wracając od niego. Nie prowokowałem do wypowiedzi specjalnie moich 
asystentów, po prostu był to naturalny proces. Oczywiście dopytywałem o pewne kwestie, których nie rozumiałem w pełni. Oni byli całkowicie otwarci, wiedzieli że to, co robimy, ma sens, opiera się na wzajemnym zaufaniu, a to zaufanie - jak sądzę - musi być wsparte charakterem badacza i jego autorytetem.

Przez moich asystentów byłem przedstawiany miejscowym jako antropolog, który przyjechał z Polski, z Europy, po to, żeby poznać życie miejscowej ludności i jej bieżące problemy. Mapucze, z którymi rozmawialiśmy, zawsze na samym początku pytali, czy przypadkiem nie mam jakiegoś związku z Bankiem Światowym albo z norweską firmą, która w Araukanii budowała elektrownię wodną. Tego rodzaju powiązania byłyby dla mnie dyskredytujące ze względu na fatalną opinię tych instytucji w oczach miejscowych. Prócz braku tego rodzaju powiązań moim atutem było zainteresowanie nie tylko kwestiami badawczymi, lecz także ich codziennymi problemami, co pomagało w pokonywaniu znacznego dystansu. Sadzę, że w jakiś sposób im to schlebiało. Tym bardziej że wiedzieli, iż nikt mnie specjalnie nie opłacał, aby ich oszukać i uzyskać ich kosztem korzyści dla wrogich im agend. Dochodzi do tego bardzo specyficzny czynnik związany z Chile i relacjami tego kraju w epoce po dyktaturze Pinocheta z Unią Europejską. Mianowicie, w tym układzie politycznym, Mapucze świetnie zdają sobie sprawę, że przyjeżdżający do nich z Europy naukowcy, dziennikarze, ekolodzy czy prawnicy, zajmujący się problemem łamania praw człowieka, mają wpływ na kształtowanie w świecie realistycznego obrazu tego, co się dzieje z tubylcami w Chile. Tubylcy zdają sobie sprawę, że Unia Europejska i stowarzyszone z nią organizacje pomagają Indianom za pośrednictwem programów pomocowych. Nie jest to zamknięta społeczność, jej członkowie podróżują po świecie, więc orientują się, jakie znaczenie ma budowa przemawiającego do ludzi obrazu. I to mi właśnie pomagało, bo przekonujący był dla nich mój zamiar napisania kilku artykułów, których celem byłoby opisanie ich społeczności i problemów, z którymi się codziennie mierzą. Taki argument gdzie indziej byłby bezzasadny.

Kolejnym problem związanym z zaufaniem jest kwestia sposobu opisywania i przekazywania informacji o badanej społeczności. Antropologowie chilijscy nawet ci, którzy nie byli wmontowani w rozmaitego rodzaju studia aplikacyjne powiązane z przedsięwzięciami biznesowymi - nierzadko publikowali doniesienia o negatywnych cechach obserwowanych wśród tubylczej ludności: nepotyzmie, malwersacjach finansowych, o dwulicowości przywódców. Te opinie docierały szybko do Mapuczy. Wśród nich są osoby dobrze wykształcone - nauczyciele, naukowcy, artyści czy prawnicy. Wystarczyło, że ktoś przeczytał artykuł zawierający takie treści i przekazał te informacje reszcie społeczności. Niezależnie od tego, czy były one prawdziwe, przesadzone czy źle zrozumiane, przyjmowano je jako dowód niechęci świata białych do tubylców. Zauważyłem, że Indianie pamiętają nazwiska badaczy, co do których mają konkretne i poważne pretensje, w efekcie przenoszą się one na całe chilijskie środowisko antropologiczne.

Zastanówmy się teraz, co antropolog najskuteczniej robi w najkrótszym czasie? Przyjeżdża z daleka i od razu dzieli lokalną społeczność. Od czasu, kiedy zaczyna pracować z nią antropolog, grupa dzieli się na tych, którzy współpracują 
z antropologiem i, przykładowo, czerpią z tego korzyści (bo ów pomaga w założeniu jakiegoś mikroprzedsiębiorstwa albo opłaca pracujących z nim ludzi), i na resztę, która nie ma dostępu do tych korzyści. Automatycznie powstaje podział między tymi, którzy zazdroszczą innym uprzywilejowanej pozycji, a tymi, którzy zostali wyróżnieni. Na szczęście nie należałem do wspomnianych kategorii badaczy, byłem swego rodzaju „wolnym ptakiem”, który przybywa na pewien czas, nikomu nie zagraża i zabiera pozyskane informacje na drugi koniec świata.

Wspomniał Pan o zagrożeniach płynących z obecności antropologa. $W$ takim razie, jakie są granice tego, co możemy robić $w$ terenie, co jest dopuszczalne dla antropologa podczas pracy terenowej?

Trudno na to pytanie odpowiedzieć. W terenie człowiek powinien zachowywać się jak w życiu, czyli przyzwoicie. Podczas badań nie traci aktualności pytanie: co jest niedopuszczalne w moim życiu codziennym? Wiele rzeczy jest niedopuszczalnych i my o tym dobrze wiemy - nie powinienem nikogo obrażać, nie powinienem zachowywać się nieodpowiednio, nie powinienem narażać godności innych na szwank. Te wszystkie zasady obowiązują tak samo zarówno we własnym świecie, jak i w terenie, tylko że tam powinny być przestrzegane w dwójnasób. W terenie antropolog jeszcze bardziej musi hamować wszystkie swe napięcia i frustracje. Myślę, że nie powinien za bardzo się fraternizować z miejscowymi. To do niczego dobrego nie prowadzi, bo pamiętajmy o tym, że antropologowi wydaje się, że jest dobrze zadomowiony w obcej kulturze. Ale tak do końca przecież nie jest, nie jest on jej członkiem i nigdy nie wie, w jaki sposób może być przedmiotem manipulacji. Dlatego też cały czas powinien być ostrożny i kontrolować siebie.

Podczas badań terenowych wielokrotnie próbowano mną manipulować. To wielkie niebezpieczeństwo, bo godzi przede wszystkim w rzetelność i efektywność badań. Prowadzi to nierzadko do tego, że jedni informatorzy chcą z badaczem rozmawiać, natomiast inni postrzegają go za stronnika swych „Wrogów” i odmawiają współpracy. W terenie często można spotkać się z chęcią "zawłaszczenia” przybysza w oczekiwaniu na potencjalne benefity wynikające z takiej znajomości, wobec czego otacza się go kordonem - „on będzie nasz a nie wasz". W dużym stopniu prowadzi do tego właśnie familiaryzowanie się. W terenie powinno się zachowywać neutralność. Wchodząc w nowe środowisko, nie mamy pojęcia, jak lokalna społeczność jest podzielona, jakie jej członkowie mają poglądy polityczne czy religijne, jakie występują napięcia między "młodymi” a "starymi”, "tradycjonalistami” a "postępowcami”. W związku z tym najlepiej zachować dystans i starać się ze wszystkimi stronami utrzymywać dobre relacje.

Czasami pojawiają się i odwrotne pretensje - miałem z tym często do czynienia podczas badań Polaków żyjących w Kazachstanie. Pytano mnie tam z wyrzutem: „Dlaczego nie przyszedłeś do nas, a odwiedziłeś sąsiadów?”. Jak miałem komuś wytłumaczyć, że po prostu nie znalazł się on na liście potencjalnych informatorów bądź że nie wiedziałem o jego istnieniu? Albo że po prostu zabrakło czasu i ,już wyjeżdżamy”. Taka osoba brak zainteresowania z naszej strony przyjmować może jako wyraz świadomego zignorowania jego pozycji 
społecznej. Badacz, żyjąc w danym środowisku, musi utrzymywać bardzo delikatną równowagę i starać się nie wyróżniać nikogo. Nie zawsze jest to możliwe, ale przynajmniej powinien się starać być wyczulonym na tego rodzaju niuanse.

Jedną rzeczą, której należy się absolutnie wystrzegać, to odmowa gestu gościnności. Czasami jest to bardzo dolegliwe, szczególnie w egzotycznych kulturach, kiedy tubylcy z sympatii dla przybysza częstują go swoim jadłem, które może nam nie smakować, przyrządzonym $\mathrm{w}$ niehigienicznych warunkach i podanym w niezbyt czystym naczyniu. Nie można dać odczuć tym ludziom, że to nas napawa obrzydzeniem, że boimy się o swoje zdrowie ze względu na groźbę zarazków i pasożytów. Nawet zdając sobie sprawę, że możemy narazić się na uszczerbek na zdrowiu, powinniśmy w minimalnym zakresie sprostać tej sytuacji. Ewentualne choroby wynikające z pracy w terenie należy wkalkulować w ryzyko prowadzenia tego rodzaju badań. Nie ma takiej możliwości, aby powiedzieć „nie, dziękuję”, jeśli ludzie częstują przybysza i czynią to na dodatek w sposób ceremonialny. Zgodnie z zasadą takiego działania poczęstunek i jego przyjęcie to symbol pierwszego etapu włączenia przybysza do lokalnej wspólnoty. W takich sytuacjach zawsze sobie mówię: „Wszelkiego rodzaju niedogodności badacz musi znosić ze stoickim spokojem". Oczywiście człowiek jest tylko człowiekiem, denerwuje się, szlag go trafia albo jest mu nieprzyjemnie, gdy jest źle traktowany - ale musi swe uczucia trzymać na wodzy, mimo że w podobnych sytuacjach we własnym środowisku zachowałby się z pewnością inaczej. Tam, w miejscu naszych badań, musimy zacisnąć zęby i udawać, że wszystko jest $\mathrm{w}$ porządku. W związku z tym wykształciłem w sobie wewnętrzny mechanizm, który ułatwia mi przejście przez te trudności. Mówię sobie: „To jest tylko profesjonalna sprawa”, albo - „Nic się nie martw, to jest część twojego zawodu, musisz przez to przejść". W związku z tym, jeżeli ktoś mnie obraził czy źle potraktował, to nie mam powodu, by się tym szczególnie denerwować. Jestem przecież tam po to, aby wykonać solidnie zadanie naukowe. Smutki i radości, wyrazy oburzenia czy aprobaty wyrażane pod moim adresem nie mogą dotykać mojego "Ja", dotyczą bowiem tylko antropologa, który został tam wysłany nie po to, żeby się obrażał, wściekał, denerwował. Niewątpliwie nie jest to przyjemne, czasami bowiem trzeba cierpieć niewygody, brud, złe relacje, a nawet niebezpieczeństwa ale łatwiej można to wszystko znieść, gdy uzmysłowimy sobie, że w tej sytuacji są to elementy wpisane $\mathrm{w}$ naszą naukową profesję.

To jedna z ważnych dewiz, żeby kontrolować swoją psychikę. Trudna to sztuka, bo im dłużej się jest $\mathrm{w}$ terenie, tym kondycja psychiczna jest zdecydowanie słabsza. Znamy to choćby z pamiętnika Bronisława Malinowskiego (2008). Jego frustracja nie miała nic wspólnego z rasizmem, co poniektórzy mu niesłusznie imputowali (por. Posern-Zieliński 1986). Weźmy podobną sytuację sprzed wielu lat. Rzecz działa się podczas wyprawy badawczej wysoko w górach Peru ${ }^{5}$. Mieszkaliśmy w obozie utworzonym z kilku namiotów, wokół których

\footnotetext{
${ }^{5}$ Wyprawa ta została opisana w książce autorstwa Aleksandra Posern-Zielińskiego (1985) Kraina Inkarri. Szkice etnologiczne o Peru.
} 
rozciągnęliśmy sznurek sygnalizujący, gdzie jest granica zajętego przez nas terytorium. Wstawałem codziennie skoro świt, około godziny szóstej czy siódmej. Po opuszczeniu namiotu nalewałem do miski wodę, aby się umyć, i w momencie gdy podniosłem głowę, zobaczyłem dookoła - zaraz za wspomnianym sznurkiem - liczne postacie wpatrujące się, jak to gringo przystępuje do porannej ablucji. Indianie byli widać ciekawi, co przybysz robi: czy kaszle, czy smarka, czy myje twarz, czy tylko ręce, czy idzie sikać i dokąd się w tym celu udaje? Pierwszego dnia jest to być może doświadczenie interesujące, ale po kilku dniach podobnych obserwacji w człowieku wręcz buzuje. Rodzi się rozdrażnienie oraz wewnętrzna agresja, gdyż każdy chciałby przecież mieć chwilę intymnej prywatności, której $\mathrm{w}$ tej sytuacji niemal nie było. To właśnie takie momenty, prowokują do rzucania najgorszymi słowami, ale antropolog musi te naturalne uczucia zdusić $\mathrm{w}$ sobie i zachować je wyłącznie dla siebie. Pamiętnik Malinowskiego służył właśnie temu (por. Winkin 2007: 117). W pełni rozumiem tego typu działanie. Na dodatek Malinowski był tam całkowicie sam - a ja byłem z kolegami - i to on był stale obserwowany, co przedstawiono trafnie w słynnej książce George'a Stockinga (1985) Observers Observed.

Antropolodzy w terenie cały czas są obserwowani, to jedno $\mathrm{z}$ tych uwarunkowań badań terenowych, o którym trzeba pamiętać. W tym czasie nie tylko muszę kontrolować sam przebieg badań w różnych jego aspektach, lecz także samego siebie i swoją psychikę. Wszystko musi być pod kontrolą i nie sądzę, żeby każdy się nadawał do tego rodzaju pracy. Gdyby tak było, musielibyśmy błędnie - z punktu widzenia psychologii - założyć, że każdy z nas jest taki sam. A przecież wiemy, że tak nie jest. Każdy ma inną psychikę, a zatem jeżeli wymagania związane z prowadzeniem badań są bardzo do siebie podobne, to należy uznać, że nie każdy antropolog do tego zadania osobowościowo pasuje. Stąd odpowiedź, dlaczego niektórzy z naszych kolegów unikają badań terenowych jak ognia. Po prostu im to nie leży, oni się zazwyczaj do tego nie przyznają, za to będą twierdzili, że interesuje ich teoria kultury czy inny podobny aspekt ogólny. Myślę, że w takich sytuacjach przyczyna unikania badań terenowych może polegać na niedostosowaniu psychiki do tego rodzaju zadań lub na słabej umiejętności zaadaptowania się do warunków tak wymagającej pracy.

Jeśli wyjeżdżamy na kilka dni w teren etnograficzny położony w Polsce, to po powrocie błyskawicznie odreagowujemy nasze ewentualne stresy. Jeżeli jednak jesteśmy dzień po dniu w odległym kraju, z dala od rodziny, w obcym otoczeniu, to myśli zaprzątają nam dziesiątki spraw - również finansowych - jak wszystko ze sobą zgrać, żeby badania się udały. Również to zadanie jest szalenie męczące i wyczerpujące psychicznie. Muszę powiedzieć, że z biegiem lat nabyłem większej biegłości w prowadzeniu badań terenowych. Nie wiem, gdzie leży tego przyczyna, ale prawdopodobnie liczy się przede wszystkim element doświadczenia, który wpływa na stopniowe zwiększanie się psychicznej tolerancji na różne, niekiedy wręcz skrajne sytuacje. Człowiek młody jest z natury impulsywny, w znacznie większym stopniu przeżywa powodzenia i trudności, u osób starszych ten próg tolerancji jest wyższy. Dzięki temu zdecydowanie 
łatwiej psychicznie znoszę obecnie prowadzone badania, niż miało to miejsce piętnaście czy dwadzieścia lat temu.

Jak w takim razie rysuje się kwestia etyki w badaniach antropologicznych?

Kiedy mówimy o etyce, to musimy uwzględnić kilka poziomów. Zależy, o którym z nich będziemy mówić. Pierwsza sprawa, to etyczne sposoby zdobywania informacji; innym zagadnieniem będzie etyka zachowania się badacza w terenie. Podczas rutynowej pracy na uczelni można się poprawnie zachowywać od godziny 8 do 17, aby z kolei wieczorem, już w prywatnym czasie, nadużyć alkoholu i wywołać awanturę w barze. Tymczasem w trakcie badań terenowych zachowania etyczne muszą obejmować kwestie zarówno zawodowe, jak i pozazawodowe. W zwyczajnym życiu domowym te dwie strefy można nieco od siebie oddzielić, natomiast w terenie niestety one się w całości pokrywają i na tym polega problem. Etyka życia osobistego i zawodowego jest ze sobą sprzęgnięta całkowicie, bo jest istotne to, jak się badacz zachowuje, czy - powiedzmy - biega obnażony, dostawia się do miejscowych dziewczyn, czy womituje pod kaktusem... Ludziom, którzy nie potrafią się w pełni kontrolować można tylko radzić, aby w teren nie jeździli. Codzienne zachowania badacza mają bowiem także wpływ na to, jak jest on postrzegany i jak ludzie, wśród których przebywa, na niego reagują. Podstawowa zasada pracy antropologa zawiera się w stwierdzeniu, że nie możesz ranić w żaden sposób innych, ani dawać im powodu, by poczuli się urażeni. Przestrzeganie tej reguły nie jest łatwe, bo przecież nie znamy w wystarczającym stopniu kodu kulturowego tubylców, od których w istocie zależymy, którzy nas goszczą i od których my czegoś chcemy.

Fundamentalna dla czynnego antropologa jest zatem etyka w relacjach z ludźmi. To w gruncie rzeczy sprawy zdroworozsądkowe, bo tego nie można się nauczyć z podręcznika, po prostu trzeba być porządnym człowiekiem w każdej sytuacji. Do tego dochodzi kwestia samoprezentacji względem lokalnej społeczności. Nie powinniśmy w terenie stwarzać sytuacji totalnej mistyfikacji, ukrywając rzeczywiste powody naszej tam obecności. Oczywiście w terenie zawsze mamy kłopoty z tym, jak wyjaśnić, kim jesteśmy, bo to, że przedstawimy się jako antropolog, to dla badanych przez nas ludzi nic nie znaczy. Trzeba zatem w miarę przystępnie wyjaśnić, jakie mamy zadania i cele, najlepiej za pomocą kategorii możliwych do zrozumienia przez miejscowych. Natomiast - podkreślam to - nie powinno się intencjonalnie kamuflować własnej tożsamości. Udawanie kogoś innego (turysty) jest niedopuszczalne. Antropologiem jest się bowiem cały czas, a nie tylko od święta czy w godzinach służbowych. Jasne, że nie musimy chodzić z etykietką: "Jestem antropologiem, uważajcie! Obserwuję was". Jako antropolog rzeczywiście mam nawyk, aby cały czas obserwować ludzi w każdym miejscu: $\mathrm{w}$ autobusie, w barze, na ulicy czy na przyjęciu; w wolnych chwilach specjalnie udaję się w takie miejsca codziennego życia, aby poobserwować, jak ludzie się tam zachowują, jak żyją. To daje mi ogólny ogląd lokalnej sytuacji. Wtedy też nie muszę się nikomu tłumaczyć z moich obserwacji. Czynię to jednak niejako prywatnie. To oczywiście inna sytuacja, bo opiera się na anonimowości. W każdych jednak okolicznościach trzeba przestrzegać dobrych obyczajów swojej kultury, 
a także możliwie szybko poznać reguły dobrych obyczajów kultury miejscowej. Najtrudniejsze jest balansowanie między jednym i drugim kodem etycznym tak, aby nikogo nie urazić.

Podczas jednego z moich pobytów w Stanach Zjednoczonych prowadziłem badania nad społecznością skupioną przy parafii polonijnej (por. Posern-Zieliński 1982, 2016). Okazało się, że byłem manipulowany w bardzo perfidny sposób, i to do tego stopnia, że próbowano wykorzystać mnie jako eksperta od spraw Polonii w celu interwencji w miejscowym episkopacie. W związku z tym zostałem głęboko wplątany w konflikt wewnątrz wspólnoty parafialnej, rozgrywający się między starą i nową Polonią, między Amerykanami polskiego pochodzenia a Polakami przybyłymi do USA w okresie lat 80 . XX w. Kwestia ta nie była przedmiotem moich planowanych badań, ale objawiła się nagle i trudno byłoby ją ignorować. Okoliczności tego konfliktu były dla mnie dodatkowym i ważnym źródłem informacji. Zacząłem zbierać materiały dotyczące tego zagadnienia z zamiarem napisania na ten temat pracy. Ponadto, nieco później, od jednego z moich znajomych otrzymałem całą dokumentację historyczną dotyczącą wspomnianego konfliktu, który sięgał swymi korzeniami jeszcze okresu sprzed mojego przybycia do Stanów Zjednoczonych. To był fascynujący materiał, znakomicie nadający się do pokazania znacznie szerszych procesów dotyczących przemian świadomości migrantów, kształtowania się ich tożsamości czy roli parafii jako enklawy polskości. Po zastanowieniu stwierdziłem jednak, że niewiele na ten temat mogę napisać poza dość ogólnikowymi refleksjami. Może po latach od czasu tego konfliktu zabiorę się do tego tematu? Ale to już nie będzie tak atrakcyjne zagadnienie, a do tego cała tak ważna dla antropologa świeżość spojrzenia całkowicie przeminęła; moje ówczesne pełne zanurzenie $w$ tych wydarzeniach dawało mi potencjalnie silny impuls do ujęcia tego tematu w sposób oryginalny i bardzo osobisty. Tymczasem dzisiaj są to tylko materiały historyczne. Podejmując taką decyzję, stwierdziłem, że nie sposób byłoby analizować wydarzenia i konflikty, a następnie ich wyniki publikować z zachowaniem anonimowości polonijnych "bohaterów”. Zdałem sobie sprawę, że wszystko zostałoby ujawnione i mogłoby jeszcze bardziej zaognić lokalną sytuację. Gdybym opublikował te rozważania pod swoim nazwiskiem, to wiadomo byłoby, gdzie w Stanach Zjednoconych przebywałem przez rok, w jakiej miejscowości żyłem i jaką społeczność opisywałem. Wszystko byłoby zatem odczytane jednoznacznie i, być może, wykorzystane przeciwko jednej albo drugiej stronie. Na to nie mogłem sobie pozwolić. Byłem bardzo zaprzyjaźniony z tymi ludźmi, przebywałem wśród nich bardzo długo. To były bardzo bliskie, wręcz familijne kontakty. Zrezygnowałem zatem z publikacji. To względy, które trzeba umieć zauważyć, zdawać sobie z nich sprawę, umieć wyciągnąć bolesne wnioski, do czego - jak sądzę - nie każdy jest przygotowany.

Należy zadać sobie pytanie, jakie są granice etyki? Dla jednej osoby sięgnięcie po cudzy kubek z wodą może stanowić przyczynek do refleksji etycznej, zaś dla kogoś innego bodźcem do takiej refleksji staje się dopiero kradzież czy morderstwo. W codziennym życiu nie dostrzegamy wielu problemów tego rodzaju 
z dostatecznym wyprzedzeniem. Tym bardziej nie postrzegamy jednakowo tego, czy postępujemy niewłaściwie w określonych okolicznościach. Niektórzy nie widzą tego, że zachowują się nieetycznie. Dlatego też powstały kodeksy etyczne (por. Seweryn 2010). Jednymi z pierwszych, którzy je tworzyli, byli oczywiście Amerykanie. Wszelkie zachowania i postępowania ujmują oni w ramy kodeksów i podręczników łopatologicznie wykładających, jak zdobyć przyjaciela czy, jak chodzić, by schudnąć. Nie negując wagi właściwie sformułowanych zaleceń etycznych dopasowanych do konkretnego zawodu, warto jednak zdać sobie sprawę i z tego, że istotną busolą w naszym postępowaniu powinno być poczucie przyzwoitości, szacunku do Innego oraz wyczucia, co nam wolno, a czego nie powinniśmy pod żadnym pozorem czynić.

Poznań, 22.02.2012 r.

\section{Literatura}

Armon, K. (2007). Witold Armon, 1924-2002. W: E. Fryś-Pietraszkowa, A. Spiss (red.), Etnografowie i ludoznawcy polscy. Sylwetki, szkice biograficzne. T. 1 (s. 5-9). Wrocław-Kraków: Polskie Towarzystwo Ludoznawcze, Oddział Polskiego Towarzystwa Ludoznawczego w Krakowie.

Armon, K., Armon, W. (2007). Eugeniusz Frankowski, 1884-1962. W: E. Fryś-Pietraszkowa, A. Spiss (red.), Etnografowie i ludoznawcy polscy. Sylwetki, szkice biograficzne. T. 1 (s. 98-103). Wrocław-Kraków: Polskie Towarzystwo Ludoznawcze, Oddział Polskiego Towarzystwa Ludoznawczego w Krakowie.

Bednarski, J. (2011). Instytut Etnologii i Antropologii Kulturowej Uniwersytetu imienia Adama Mickiewicza w Poznaniu. Ethnologia Europae Centralis, 10, 98-105.

Buchowski, M. (2005). Ku odpowiedzialnej antropologii. (op.cit.,) maszyna interpretacyjna. pismo kulturalno-spoteczne, 1(22), 6.

Gawryck, M.F. (2011). Podglądając Innego. Polscy trawelebryci w Ameryce Łacińskiej. Warszawa: Wydawnictwa Uniwersytetu Warszawskiego.

Kościańska, A. (2004). Ku odpowiedzialności. Etnologia w Polsce: tradycje i wyzwania. (op.cit.,) maszyna interpretacyjna. pismo kulturalno-społeczne, 6-7(19-20), 12-13.

Kowalewski, J., Piasek, W. (red.). (2009). Antropologizowanie humanistyki. Zjawisko - proces - perspektywy. Olsztyn: Instytut Filozofii Uniwersytetu Warmińsko-Mazurskiego w Olsztynie.

Labuda, G. (1954). Słowiańszczyzna pierwotna. Wybór tekstów. Warszawa: Państwowe Wydawnictwo Naukowe.

Malinowski, B. (2008). Dziennik w ścistym znaczeniu tego wyrazu. Kraków: Wydawnictwo Literackie.

Moszyński, K. (1958). Człowiek. Wstęp do etnografii powszechnej i etnologii. Wrocław-Kraków-Warszawa: Zakład Narodowy im. Ossolińskich.

Nocoń, R.H. (1958). Dzieje, kultura i upadek Inków. Wrocław: Zakład Narodowy im. Ossolińskich.

Paluch, A. (2012). W drodze do prawdy - jakiej?. Wrocław: Katedra Etnologii i Antropologii Kulturowej Uniwersytetu Wrocławskiego. 
Paradowska, M. (2002). Maria Frankowska, 1906-1996. W: E. Fryś-Pietraszkowa, A. Kowalska-Lewicka, A. Spiss (red.), Etnografowie i ludoznawcy polscy. Sylwetki i szkice biograficzne. T. 1 (s. 92-97). Kraków: Wydawnictwo Naukowe DWN.

Pomieciński, A., Sikora, S. (red.). (2009). Znikajace granice. Antropologizacja nauki i jej dyskursów. Poznań: Biblioteka Telgte.

Posern-Zieliński, A. (1982). Tradycja a etniczność. Przemiany kultury Polonii amerykańskiej. Wrocław: Zakład Narodowy im. Ossolińskich.

Posern-Zieliński, A. (1985). Kraina Inkarri. Szkice etnologiczne o Peru. Wrocław: Zakład Narodowy im. Ossolińskich.

Posern-Zieliński, A. (1986). Bronislaw Malinowski's „antilegend” in Soviet and Polish criticism. The Polish Review, 31(4), 285-298.

Posern-Zieliński, A. (2010-2011). The Mapuche from Araucania: Their identity, ethnic activism and attitudes toward the state. Ethnologia Polona, 31-32, 191-205.

Posern-Zieliński, A. (2011). Indianie a państwo w Ameryce Łacińskiej: tubylczy aktywizm wobec etnopolitycznej dominacji władzy. W: K. Derwich, M. Kania (red.), Ruchy społeczne i etniczne w Ameryce Łacińskiej (s. 29-54). Kraków: Wydawnictwo Uniwersytetu Jagiellońskiego.

Posern-Zieliński, A. (2012). Indianie w metropoliach Ameryki Południowej. W: J.E. Zamojski (red.), Migracje i wielkie metropolie (s. 267-288). Warszawa: Neriton.

Posern-Zieliński, A. (2016). Między Teksasem a Greenpointem. Różne oblicza polskiej imigracji w Stanach Zjednoczonych. W: N. Bloch (red.), Wszyscy jesteśmy migrantami. (Od)zyskiwanie pamięci migracyjnej (s. 98-111). Poznań: Centrum Kultury Zamek.

Robotycki, C. (1995). O banalizacji tekstów w etnologii. W: A. Posern-Zieliński (red.), Etnologia polska między ludoznawstwem a antropologia (s. 83-87). Poznań: Drawa.

Seweryn, A. (2010). Kodeks etyczny antropologa. W: K. Kaniowska, N. Modnicka (red.), Etyczne problemy badań antropologicznych (s. 33-51). Wrocław-Łódź: Polskie Towarzystwo Ludoznawcze.

Stocking, G.W. (1985). Observers Observed. Essays on Ethnographic Fieldwork. Madison: University of Wisconsin Press.

Szyfer, A. (2006). Zapisane w pamięci. Z badań etnografa. Poznań: Wydawnictwo Poznańskiego Towarzystwa Przyjaciół Nauk.

Tatarkiewicz, W. (1958). Historia filozofii. T. 1-3. Warszawa: Państwowe Wydawnictwo Naukowe.

Walczak, B. (2009). Antropolog jako Inny. Od pierwszych badań terenowych do wyzwań ponowoczesnej antropologii. Warszawa: Wydawnictwo Naukowe Scholar.

Winkin, Y. (2007). Antropologia komunikacji. Od teorii do badań terenowych. Przeł. A. Karpowicz. Warszawa: Wydawnictwa Uniwersytetu Warszawskiego. 